PIOTR ZWIERZCHOWSKI

Kazimierz Wielki University in Bydgoszcz

\section{Functions of film images of Warsaw in the Polish cinema of the 1960s}

\section{Images} vol. XXII/no. 31 Special Issue Poznań 2017 ISSN 1731-45OX

\begin{abstract}
Zwierzchowski Piotr, Functions of film images of Warsaw in the Polish cinema of the 1960s. "Images" vol. XXII, no. 31. Poznań 2017. Adam Mickiewicz University Press. Pp. 65-78. ISSN 1731-450X. DOI 10.14746/i.2017.31.07.

Polish cinema of the 1960s presented a specific vision of Warsaw, different from earlier and later ones, although it contained some solid motifs for the entire PRL era. These include emphasizing the uniqueness of Warsaw, the war past as an inseparable part of the city's identity (though in the 1960s with a slightly different meaning) or the problem of getting a flat. The separateness and specificity of the then created images of the capital was related to the political specificity of the decade, the cultural and social moment of Warsaw development, the domination of realism that made the message authentic and genological issues - the main role in creating the image of the city was played by comedy. These images, however, were sometimes surprisingly subversive, breaking the dominant image.
\end{abstract}

KeYworDs: Polish cinema, 1960s., Warsaw, film images, comedy

Of all its cities, Warsaw not only appears in Polish film most often, but also has a special place in it. It is a city that is significant both as a capital and as a city-symbol in the Polish cultural space. However, as Ewa Mazierska rightly states, "it is impossible to talk straight about a film city, just like about a city as such any discussion means in fact concentrating on some aspect of its representation, and thus omitting many other aspects." [1]

In this text, I would like to focus primarily on the film representations of Warsaw in the cinema of the 1960s. The city was very often just the place where the film action is set and which can be easily identified even for someone who does not live in the capital (though on the other hand it was the films that made some of Warsaw's locations known to all viewers). However, one can also assign various functions to its images. Warsaw was most often used to promote modernity and socialism, still without, avoiding references to tradition. The legitimational and ideological functions were essential, which does not mean that they were the only ones. They were connected with the ludic, dramaturgic, aesthetic[2] or cognitive ones, which, in turn, also occurred independently. Obviously, it is sometimes difficult to separate them. It is also worth noting that sometimes these images were surprisingly subversive, breaking the dominant image.

[1] E. Mazierska, Janusowe oblicze filmowego miasta, "Kwartalnik Filmowy" 1999, no. 28, p. 38.
[2] In this context, it is necessary to mention the film that is so different from other ones about Warsaw Lalka [The Doll] (1968) by Wojciech Jerzy Has. 
The cinema of the 1960 s presented a specific vision of Warsaw, different from the previous and later ones, although it contained, of course, some motifs that were inchanging through the entire Communist era Poland. It is obvious that they had to be repeated irrespective of the decade. They included the emphasis on the unusualness and uniqueness of Warsaw, the wartime past as an inseparable part of the city's identity (though in the 1960 this had a slightly different meaning) or the problem of getting a flat. The separateness and specificity of the images of the capital created at the time were connected with the political specificity of the decade, the cultural and social moment of the development of Warsaw, the domination of realism that made the message authentic and with genological issues the main role in creating the image of the city was played by comedy.

After the Second World War, Warsaw was a city-martyr, especially until 1948, and then a city-phoenix, reborn from the ashes. From the mid-1950s, in the "black series" of Polish documentaries, in such films as: Gdzie diabeł mówi dobranoc [Where the Devil Says Goodnight] (1956) and Ludzie z pustego obszaru [People from an Empty Area] (1957) by Kazimierz Karabasz and Władysław Ślesicki, Warszawa 1956 [Warsaw 1956] (1956) by Jerzy Bossak and Jarosław Brzozowski, Miasto na wyspach [City on the Isles] (1958) by Bohdan Kosiński and Jerzy Dmowski, Z Powiśla [From Powiśle] (1958) by Kazimierz Karabasz, Warszawa $B$ [Warsaw B] (1960) by Jerzy Dmowski.

the pride of the capital city turns into its explicit criticism, and documentarians, presenting cases from specific districts of Warsaw, treat them as universal stories about the ills and pathologies of the whole society which struggled with difficulty after the war trauma.[3]

Films made the audience aware of the existence of a different Warsaw to the one presented so far in films and chronicles. They revealed at the same time social problems far beyond the limits of the capital. In the 1960 s this was supposed to change. The beginning of the decade is marked, not only symbolically, by the Resolution of the Communist Party Central Committee Secretariat about the cinema. Of course, it did not contain any references to Warsaw, but since the cinema was supposed to "reflect the subject of contemporary life marked by truth and realism," [4] the film portraits of the capital had to be made in this spirit. Therefore, Niewinni czarodzieje [Innocent Sorcerers] (1960) by Andrzej Wajda encountered Władysław Gomułka’s dislike. Warsaw was real in this film, yet not entirely real; young people were absorbed in it (the camera looks into fashionable clubs and places[5]) however, in the film there is none of the modernity that the decision-makers wanted

[3] M. Smoleń, Pod warszawskim adresem: wyobrażenia i realia. Dokumentalne opowieści o stolicy, jej mieszkańcach i prowincjonalnych "słoikach", "Images" 2013, no. 21, p. 196.

[4] Uchwała Sekretariatu KC w sprawie kinematografii, in: Syndrom konformizmu? Kino polskie lat sześćdziesiątych, ed. T. Miczka, A. Madej, Katowice 1994, p. 31.

[5] Stanisław Ozimek recalled the words of Andrzej

Wajda: "If it were possible to make a cross-section of the city, a panorama of Warsaw." S. Ozimek, Od wojny w dzień powszedni, in: Historia filmu polskiego, vol. 4, 
to see. It was not difficult to accuse this motion picture of "detachment from the particulars and conditions of the social reality of Poland which was building socialism." [6]

The statements above, included in the Resolution of Central Committee... and Gomułka's speech, are very general, but it was obvious that the modern Warsaw should be promoted: not forgetting the past, the present should be highlighted. The cinema then fits into the process of giving Warsaw a new identity. It is true that the reconstruction has not finished yet, but the new Warsaw already exists, it is not a being in statu nascendi. Interestingly, in the 1960 os we rarely watch a city under construction with blocks being erected or urban transformations, so characteristic of socialist realism, and also appearing in later decades.

I would venture a thesis that when the capital of Poland had finally been formed from rubble, it lost much of the filmmakers' sympathy. Instead of celebrating its vitality, the directors began to concentrate on the problems of "getting a flat" or at least a residence registration in Warsaw, like in the movie Nie ma róży bez ognia [No Rose without Fire] (1974) by Stanisław Bareja, and on the alienation of the large-concrete-block housing housing estate, as in Dekalog [Decalogue] (1988) by Krzysztof Kieślowski.[7]

Recalling the above examples, Ewa Mazierska omits the 196os. It is also noted by Monika Talarczyk-Gubała, who further mentions that her thesis is contradicted by the film comedy of this decade. Indeed, with this genre, you can see the specificity of the city's images that were characteristic of the decade. The images of Warsaw included in the comedy should be considered not in the moralistic discourse, but in the mythographic discourse associated with the myth of the city.[8] The author adds that although the domain of the comedy is destruction, it is in this specific variety of the genre, which is the Warsaw comedy distinguished by her, that we are dealing with an apology of the city.[9] Considering the entire period of Communist-era Poland, the phases of myth can be seen in these films: the founding of the city, its prosperity - that is the 1960s - and then dusk and collapse.[10] The prosperity phase would include Nie lubię poniedziałku [I Hate Mondays] (1971) by Tadeusz Chmielewski and Dzięcioł [The Woodpecker] (1970) by Jerzy Gruza.

The beginning of the 1970s brings the twilight stage in accordance with the mythological order. Although Nie lubie poniedziałku [I Hate Mondays] (1971) by Tadeusz Chmielewski is still in line with the picture presented in the previous decade (although it is more ambiguous), then films appearing at the same time, Hydrozagadka [Hydro-Riddle] (1970) and Wniebowzięci [On Cloud Nine] (1973) by

1957-1961, ed. J. Toeplitz, Warszawa 1980, p. 165. But paradoxically in this film, so much associated with Warsaw, there is relatively little of the city.

[6] W. Gomułka, O aktualnych problemach ideologicznej pracy partii, wygłoszony 4 lipca 1963 r., in: idem, O naszej partii, Warszawa 1968, p. 539.
[7] E. Mazierska, op.cit. p. 50.

[8] M. Talarczyk-Gubała, PRL się śmieje! Polska komedia filmowa lat 1945-1989, Warsaw 2007, p. 226.

[9] Ibidem, p. 227.

[10] Ibidem, p. 228. 
Andrzej Kondratiuk and Dziewczyny do wzięcia [Marriageable Girls] (1972) by Janusz Kondratiuk, put the city's charm of Warsaw in question. [11] It would be the same in the comedies by Stanisław Bareja in the 1970s. The film Warsaw, which in the 196os met the dreams of locals and visitors, turned out to be much less friendly.

This breakthrough, obviously, is associated not only with comedy. Although in the 1960s many films are still made in black and white, there is no greyness in them as a reflection of the conditions and atmosphere of life in Communist-era Poland. This phenomenon would appear only at the end of the decade, e.g. in Zbrodniarz, który ukradł zbrodnie [The Criminal who Stole the Crime] (1969) by Janusz Majewski. The documentary would, at least to some extent, be related to the "new change." Especially in the 1970s, but also in the next decade, greyness, showing material degradation of physical reality (and this also concerned the image of the city) became a metaphor of social and moral decay. Among these images of the reality in Communist-era Poland, the city plays an important role (although in the cinema of moral anxiety the action was usually located far away from the capital), constituting a dehumanized space of struggle for existence, but on the other hand only a city gives a chance of success, and the possibility of defeat.[12] Of course, there are also films promoting the expanding Warsaw, and here again, one should point out the comedy. But even in Jerzy Gruza's Czterdziestolatek [The 40-Year-Old], when engineer Karwowski bravely builds the Central Railway Station, Łazienkowska Route and Torun Route, the visual images of propaganda of success, not without irony, do not match the colourful (although still sometimes on black and white film stock) Warsaw of the 1960 .

Monika Talarczyk-Gubała rightly notes that the charms of the big city became one of the most important elements of the comedy of manners, even if it aroused ambivalent emotions in connection with colouring the reality.[13] Warsaw was a kind of synthesis of urbanity. "The film Warsaw, the first among Polish cities, determining the pace of development, imposing fashions, centrally managing other cities, embodied that cut of urbanity in popular culture." [14].

For today's viewer, Warsaw's film images are an invaluable source of knowledge about the appearance of streets, buildings, etc., about the city from before the construction of Central Station (for now its role is served by the Sródmieście Station[15]) and the Royal Castle built in

[11] Ibidem, pp. 242-243. See also D. Dabert, Jest dobrze. O ironiczności Wniebowziętych Andrzeja Kondratiuka, in: Poloniści o filmie, ed. M. Hendrykowski, Poznań 1997, p. 193.

[12] D. Dabert-Bakuła, Prowizoryczny świat na stałe. O peerelowskich szarościach w filmie lat 70. i 80., "Images" 2004, no. 3-4, p. 65.

[13] M. Talarczyk-Gubała, op.cit., p. 229.

[14] Ibidem, pp. 240-241.
[15] Śródmieście Station was used in quite a variety of ways. In Anna Sokołowska's Beata [Beata], this is a surprisingly intimate space of the final encounter between the heroine and Olek, who is in love with her, the protagonist of the Spotkanie ze szpiegiem [Meeting with the Spy] makes an appointment here with a co-worker, and in Ktokolwiek wie... [Anybody Knows...] the journalist starts the last, leading nowhere, stage of searching for Maria Ruśniak. 
the 1970s. In many films a mandatory set was included - the Old Town, Krakowskie Przedmieście Street, the Palace of Culture and Science, Łazienki Park, and new housing estates. Even if we are dealing with a propaganda image, the camera did sometimes record the elements of real life. For example, what impresses in all these films is the road traffic, which is much lighter in relation to the present day. After all, in an indirect way, it shows the pace of life.

They also allow one to notice, sometimes indirectly, what meanings and functions were then attributed to individual buildings or premises, not only in the film. Here, for example, put into use in 1951, but designed in the years 1947-1948, and thus before the official introduction of socialist realism, the Central Department Store "was synonymous with modernity, «western chic» and the European character of Warsaw. That is why it often appeared in various films, and their characters were particularly fond of this part of Jerozolimskie Avenue for walks." [16] In the 1960s, one can point out Rozwodów nie będzie [There Will Be No Divorces], Niewiarygodne przygody Marka Piegusa [The Unbelievable Adventures of Marek Piegus], Wojna domowa [Civil War], or the Lekarstwo na miłość [Cure for Love]. Thanks to these films, its original appearance from the time before the fire in 1975 was preserved.

In the second short feature of Gangsterzy i filantropi [Gangsters and Philanthropists], Warsaw residents complained about the restaurants in the capital. Indeed, they could be accused of a lot, but they were still very popular.[17] The film by Jerzy Hoffman and Edward Skórzewski is an interesting contribution to the history of everyday life in Warsaw. But this film, in addition to proving that all the inconvenience that the characters experience (similarly e.g. to Nie lubię poniedziatku [I Hate Mondays]) arises from human mistakes, attitudes and misunderstandings, but never from the essence of the system, [18] also a confirmation of Warsaw's metropolitan aspirations. The restaurants that were once fashionable, recognizable not only to the residents of Warsaw, were a sign of metropolitan life, usually treated positively, as in Lekarstwo na miłość... but sometimes also with distance, as can be seen in Beata [Beata]. Some of them no longer exist, so that the films showing them have become a record of the bygone world and both everyday life and imagination of that time. Kaprys was such a place, located at Smolna Street (Beata [Beata], Spotkanie ze szpiegiem [Meeting with a Spy]), or a cafe at the Central Department Store, where the heroines of Lekarstwo na mitość meet.

"Nice city, Warsaw, isn't it?" says Ciaputa in Mąż swojej żony [Husband of His Wife], showing the capital from the terrace of the Palace of Culture and Science to a young girl from the provinces. She

[16] G. Sołtysiak, Filmowy przewodnik po Warszawie, Warszawa 2007, p. 64.

[17] See B. Brzostek, Za progiem. Codzienność w przestrzeni publicznej Warszawy lat 1955-1970, Warszawa 2007, p. $401 \mathrm{ff}$.
[18] Therefore, Hoffman and Skórzewski did not get permission to make the third short feature which exposed the economic absurdities of Communist-era Poland. 
has no doubts: "Very nice." The action of this film takes place mainly in interiors, but the walk around Warsaw and the stadium scenes make the city, which is modern and friendly to both residents and visitors, seem to be one of the characters in the film. It is worth noting that the Karcz family live in a nice and functional block of flats, but in the cinema of the 196os this form of construction remains in the background. Such blocks also play an important role in Dzięciot [The Woodpecker] and are shown in many documentaries, but they are not the dominant feature, but rather an addition, while in feature films, they are usually form the background and site of action, almost not at all a subject to any analysis.

Another Warsaw was shown by Bareja in Małżeństwo z rozsądku [Marriage of Convenience]. Here, in turn, the Old Town tempts with its charm, colourful, practically spotless, an ideal place for a romantic adventure (as in the scene on the Stone Steps), but also for erotic challenges. Konrad Klejsa notes that in the films by early Bareja, those made in the 1960 , the city's presentation has a character of propaganda:

it is a well-furnished, friendly, and even idyllic space; in any case, it does not cause problems for the protagonists of the films from the mid and late stages of his work. This remark also applies to the flats of the main characters. In Małżeństwo z rozsądku [Marriage of Convenience], the charms of neat Warsaw tenement houses (and their roofs, on which beautiful girls are sunbathing naked) are displayed; in Żona dla Australijczyka [Wife for an Australian], the majority of the action takes place in an area of luxurious houses, picturesquely located right by the beach.[19]

There is no question of difficulties in obtaining a residence registration, which are shown by Bareja in Nie ma róży bez ognia (1974) [No Rose without Fire]. Warsaw is a friendly, open city, encouraging all to live here; it is a destination for young people, such as for Kasia from the third short feature of Rozwodów nie będzie (1963) [There Will Be No Divorces] by Jerzy Stefan Stawinski. The city in Maż swojej żony [Husband of His Wife] is admired by Renata who comes from Włocławek. On the other hand, Warsaw appears as a symbol of familiarity, evoking nostalgia and emotion. You can go to the West, but the protagonists are always accompanied by longing for Poland. For example, the lyrics of the song sung by Pola Raksa in Przygoda z piosenka (1968) [Adventure with a Song] by Bareja: "How come, how can it be that under the Eiffel one longs for Hoża / that at Étoile Square / I suddenly regret MDM and Wilcza Street?." [20]

But not every film presents a vision of the Promised Land in such an optimistic way. Marysia that is looked for by the main character of Ktokolwiek wie... [Anyone Knows...] by Kazimierz Kutz was probably

[19] K. Klejsa, Stanisław Bareja - nadrealizm socjalistyczny, in: Mistrzowie kina polskiego, vol. 2, ed. G. Stachówna, B. Zmudziński, Kraków 2007, p. 91. [20] Konrad Klejsa drew attention to the importance of these words praising Polish reality, Stanisław Bare- ja..., p. 117. By the way, it is worth adding that in the context of the emigration after the March 1968, a film about going to the West and longing for Poland takes on an additional meaning. 
not found in Warsaw. We will not find out what the fate of Maria Ruśniak was, but there is no doubt that one can disappear without a trace here, dissolve, remain anonymous in the crowd. What is more, few people are interested in it. A man is lonely, regardless of whether they are alone or in a crowd. To some extent, it was also shown by Henryk Kluba in the second short feature of the Szkice warszawskie [Warsaw Sketches], presenting a metropolitan picture full of neon lights, night lights, people unsuccessfully searching for another human being. Alicja Helman, noticing its resemblance to Vivre pour vivre [To Live for Life] by Claude Lelouch, wrote that

perhaps it has the excess of virtuosity, which would made us call this fragment the night landscape of Warsaw. Because ultimately, the sense of this test lies in the neon and colourful vision of the bustling metropolis, which remains the landscape of an anonymous crowd, not the story of individual human fate.[21].

The love story was superficial and unconvincing, but the city filmed in close-ups, inhabited by lonely people, became an interesting image of the modern metropolis, on the one hand real, though filtered by the technique search by Kluba, on the other referring to European patterns.

In the film description of Warsaw, absences are equally interesting. It is not, of course, about mentioning all the non-existent issues in the film, but two examples are worth noting. There is still no vision of Warsaw in the cinema of that time proposed by Tadeusz Konwicki in the literature, and which is a kind of resistance to contemporary times. It would appear only in the early 1970 in Jak daleko stad, jak blisko [How Far Away, How Close] (1971). Also only then would the cinema reach for the prose by Marek Nowakowski. At the turn of the 1950 s and 196os, his stories, collected in the volumes Ten stary złodziej [This Old Thief] (1958) and Benek Kwiaciarz [Benek the Florist] (1961), were popular. Nowakowski even worked on film projects based on them, first with Andrzej Zakrzewski and later with Andrzej Konic,[22] but they were not finalised. The picturesque microcosmos of Praga, Powiśle, Czerniaków and Wola, presented by the writer, although different when it comes to the mood, were definitely closer to the "black series" than to the images propagated in the 1960 .

This does not mean, however, that the picture of Warsaw contained in Nowakowski's books did not appear at all in the cinema of the 1960s. It became possible at the end of the decade. Krzysztof Kąkolewski, an excellent reporter, in Zbrodniarz, który ukradł zbrodnię [The Criminal who Stole the Crime], combining fiction with the real story, depicted the dark sides of the city. The story is deprived of this trace of liking for a particular group that could be felt in Nowakowski's stories. Janusz Majewski saw in The Criminal... a chance to make a film, which

[21] A. Helman, Ballady warszawskie, "Kino" 1969, no. 12 , p. 19.
[22] M. Nowakowski, Pióro. Autobiografia literacka, Warszawa 2012, p. 145. 
would be a crime movie, this special anthropological testimony[23], and a specific documentary. He wrote in his memoirs that his documentary experiences were useful in creating the world of a crime movie:

We were sometimes fortunate, and sometimes we managed to include something accidentally captured - a fight in the dark alley of Praga, a group of beer-drinkers in a bar in Swiętokrzyska Street or an authentic wino from the area of "Pigalak" who, first filmed from a hidden camera, agreed to act [in] the film and helped us a lot, showing us authentic drinking dens in the city centre.[24]

Contrary to what might seem, in The Criminal... there are not many images from Warsaw streets, the vast majority of the film takes place inside. But Warsaw, often seen from the interiors of police cars, filmed with a hidden camera, is a disturbing city. "Brukowa Street [today's Father Kłopotowski Street], one of the most peculiar streets in the capital, the relic of the past preserved in the almost museum status, has again become the witness of a tragedy." The claustrophobic well-backyard, shabby townhouses, and drinking dens of Praga are a deformed space. Agnieszka Ćwikiel thinks that

all the time, we have the impression that the images presented are exotic, that they are related to the contaminated space of the murderer and the victim. It's not your world, the viewer, it's an ugly, unimportant world - it can never be a threat to your space where the law and police work. [25]

Another thing is that when we are transferred to a house in Saska Kępa, the same music introduces a similar mood. Evil does not necessarily have to be connected with the district and housing conditions.

Filmmakers had visited Praga before, although these were relatively rare visits. Most often, they were to prove that old Praga, like other districts in which modernity was just entering or was about to enter, is now a thing of the past. Socialism and modernism would the space in which, as went the comment on Dachy [The Roofs], architectural remnants of capitalist buildings can be seen. In Mąż swojej żony [Husband of His Wife], an important role was played by the Dziesięciolecia Stadium, which had only been built a few years before. In Ballady $z$ podwórka [Ballads from the Backyard] (1961) by Bogusław Rybczyński (co-written by Krystyna Gryczełowska) Stanisław Grzesiuk sang songs from Targówek and Czerniaków. They made the neglected districts appear rather like open-air museums in which local folklore played a significant role. However, the low buildings, deserted, shabby tenement houses proved that with all the sympathy for the swashbuckling songs they are already a thing of the past. The song breaks off, and the camera moves along the old destroyed wall to see new blocks behind it and

[23] M. Czubaj, Etnolog w Mieście Grzechu. Powieść kryminalna jako świadectwo antropologiczne, Gdańsk 2010, p. 17.
[24] J. Majewski, Ostatni klaps. Pamiętnik moich filmów, Warszawa 2006, p. 86.

[25] A. Ćwikiel, U nas na komendzie, in: Syndrom konformizmu?..., p. 99. 
then Warsaw with wide streets and modern buildings. The commentary leaves no doubt:

Warsaw is changing every day. It reaches ever further with its new streets. It covers ever larger areas with new estates. It has already taken over almost all of Wola and Czerniaków. Triumphantly, it broke into Praga, soon Bródno and Annopol will be taken over. And maybe in a few years we won't be able to take pictures that we have taken today, but the song of the Warsaw street will probably remain alive forever.

The new housing estates will replace the destroyed remains after the war or even after previous years. In Paragon gola [Shoot Paragon!] and the resulting series Do przerwy 0:1 (1969) [Half Time o:1] by Stanisław Jędryka, old districts, full of ruined houses in which people live, but also of magical, unauthorised pitches (the Polonia stadium on Konwiktorska Street is also such a magical place for boys), are primarily a space for boys' adventures, sometimes dangerous, but always ending happily (despite Paragon's accident, there is no such accusation here as in Warszawa 1956 [Warsaw 1956]). At the end, the main character goes to school, probably one of the schools of the millennium. The children's adventure ends. The pitch of the boys from Wola is located next to the ruins, but one can see new blocks nearby.

And the exciting image of the Warsaw street became more and more formulaic. This concerned not only the films themselves, but also their interpretation. Henryk Kluba, who in... Ad libitum [...Ad Libitum], the third short feature of Szkice warszawskie [The Warsaw Sketches], presented, with some comedic bent, the history of a local patriot who, for the money intended for the purchase of a car, repurchases the sabre stolen from King Zygmunt's column, said:

I will be staging it in a clear contrast to the now trivialized and probably anachronistic Warsaw folklore, which was represented by Grzesiuk in a pure form. I would like a bit of poetry to be included in the short feature instead of folklore. Warsaw should be so beautiful here that it would be untrue, nature so picturesque that it would be sweet, and all taken together - tacky, colourful, festive.[26]

Regardless of the intentions of the director, the short feature was read in a more serious tone, i.e. treating it as a warm image of a Varsovian, embedded in folklore, in the scenery of colourful Warsaw, the way it appeared throughout the entire decade. Kluba managed to create a visual equivalent of this "festive" Warsaw, but there was no irony in the film, this picture was no different from dozens of others, included primarily in comedies, but also some documentaries.

These were created in large numbers, as well as film reports, travelogues, short films, and they told both about the history and modernity of Warsaw, showing people, everyday life, monuments, factories, streets, buildings, the past: Gdzieś w Warszawie [Somewhere in Warsaw] by Ta-

[26] Smak impasu, interview by Bożena Janicka,

“Kino" 1969, no. 12, p. 13. 
deusz Jaworski, Warszawska niedziela [Warsaw Sunday] by Włodzimierz Borowik, Ballady z podwórka [Ballads from the Backyard] by Bogusław Rybczyński (all 1961), Dachy [The Roofs] by Jerzy Dmowski and Włodzimierz Pomianowski, Dwie Warszawy [Two Warsaws] by Roman Wionczek (both 1962), Jej jubileuszowa mość Warszawa [Her Jubilee Majesty Warsaw] (editing film), Homo Varsoviensis by Roman Wionczek, Huta Warszawa [The Ironworks Warszawa] by Władysław Forbert (all 1965), Spotkania $z$ Warszawa (1966) [Meetings with Warsaw] by Jan Łomnicki, Pamiątka $z$ Warszawy [A Souvenir from Warsaw] by Maria Kwiatkowska, Warszawska cytadela [Warsaw Citadel] by Andrzej Szczygieł, Warszawa - lato [Warsaw - Summer] by Wanda Wertenstein (all 1967), Warszawa - lipiec 1969 [Warsaw - July 1969] by Andrzej Czałbowski, and Taka jest Warszawa [This Is Warsaw] by Krystyna Dobrowolska, Warszawa w malarstwie Canaletta [Warsaw in Canalettos Art] by Jarosław Brzozowski, Wielka warszawska [The Great Warsaw Chase] by Radosław Piwowarski (all 1969), and Warszawska opowieść [The Warsaw Story] by Roman Wionczek, Warszawski przemyst [The Warsaw industry] by Michał Gardowski (both 1970).

Most of these films were told in a similar manner and using the same motifs and functions. Indeed, original solutions were sought, but the meaning of the film had to remain unchanged. An example of that can be Dachy [The Roofs], in which the city was shown from a bird's eye view. There are no visible spaces between the buildings, which could signal the remains after war damage. The beauty of the old roofs was emphasized (it was then that Art Nouveau was appreciated), but at the same time the modern elements were clearly displayed, which in an unambiguous way referred to the current order. The logo of the " 22 Lipca" factory was dominant on the roof of the Wedel tenement house, and on the other building, the PKO sign was clearly visible. The voiceover clearly shows that no arguments, sentimental or scientific, are needed, just the visuals are enough to admire Warsaw. The conviction of its uniqueness appeared often, also expressed directly, as in Taka jest Warszawa, for example.

The uniqueness of Warsaw was also connected, or perhaps above all, with the occupation experience, with the tragedy of the destroyed city. In the 1960s, in contrast to the second half of the 1940s, the war and the immediate post-war period were less important. This does not mean, however, that the time of fighting and occupation had no meaning at all. Of course, a large number of war films were set in Warsaw although, apart from Samson (1961) [Samson] by Andrzej Wajda, Podziemny front (1965) [Underground Front] by Seweryn Nowicki and Hubert Drapelli, the first short feature of Szkice warszawskie [Warsaw Sketches] (1969) by Henryk Kluba, maybe Giuseppe w Warszawie [Giuseppe in Warsaw] (1964) by Stanisław Lenartowicz and Wniebowstapienie [Ascension] (1968) by Jan Rybkowski, the topography and genius loci of the city were of little importance. The situation of Kolumbowie [Colombuses] by Janusz Morgenstern looked a little different, for obvious reasons, 
but it was already 1970. Earlier on, the topic of the Warsaw Uprising was rather avoided, as is the case in Konrad Nałęcki's Czterej pancerni i pies [Four Tank-men and a Dog] (1966).

Wartime Warsaw appears in many documentaries, illustrating losses in the urban fabric, as well as places that are no longer there, like the Ghetto. Most often, however, the occupation images of the capital were a reference point, a kind of confirmation of the fact that the war was the origins (because such an interpretation was then accepted) of Communist-era Poland. The calm, prosperous Warsaw of the 1960 s emphatically confirmed this. Dwie Warszawy [Two Warsaws] (1962) by Roman Wionczek compared 1945 Warsaw from 1945 with the contemporary image of the capital. In Pomiędzy wrześniem a majem [Between September and May] (1968) by the same director (Colonel Zbigniew Załuski was a co-writer) a "fabulously colorful" [27] modern frame appears. Contemporary Warsaw was a confirmation that the ultimate effect of the war was Socialist Poland. It was similar in Tadeusz Worontkiewicz's Wspomnienie o bitwie [Memory of the Battle] (1967). In the film about General Zygmunt Berling, the shots presenting the peaceful life of the inhabitants of Warsaw were the final proof of the rightness of the road that began at Lenino.

The memory of the war survived in the city space although in the 1960 s it was brought to mind more by monuments and archival photographs than by the traces of wartime destruction that existed all the time. In Café pod Minoga [Lamprey Café] (1959) by Bronisław Brok the lack of the Royal Castle in the Old Town was still felt, but later the camera carefully avoided this place. One cannot see this significant emptiness in films, the action of which was taking place right next to it, e.g. in Matżeństwo $z$ rozsądku [Marriage of Convenience], the tenth episode of Wojna domowa [Civil War] or in the third short feature of Szkice warszawskie [Warsaw Sketches]. The Royal Castle became the protagonist of a film in 1971. Ludwik Perski made Losy zamku, losy kraju [The Fate of the Castle, The Fate of the Country] when Edward Gierek's team decided to rebuild it.[28]

This affirmative account of the memory, the war and the city was disturbed, though only sometimes, in episodes, short scenes. The memory of the war was not supposed to be the source of pride. The past may be something that inhibits development. In Ktokolwiek wie... [Whoever may Know...] by Kazimierz Kutz, traces of war interrupt the city life. Traffic on the streets comes to a halt when a huge dud is taken away at the beginning of the movie. Perhaps such an interpretation of this small fragment is an abuse, while Echo [Echo] (1964) by Stanisław Różewicz leaves no doubts. The Warsaw of that time, which is shown in

[27] K. Eberhardt, Świadectwo prawdy, świadectwo mitu, "Ekran" 1969, no. 35, p. 15.

[28] See S. Ozimek, Film dokumentalny, in: Historia filmu polskiego, vol. 6, 1968-1972, ed. R. Marszałek,

Warszawa 1994, p. 219.
[29] I wrote about it more extensively in the book Kino nowej pamięci. Obraz II wojny światowej w kinie polskim lat 60., Bydgoszcz 2013, p. 121. 
it, is not a joyful counterpoint to the war.[29] The city, recorded not in the official but individual memory, is dark and gloomy, reminiscent of unfriendly times. Henryk, accused of collaborating with the Germans during the war, does not find solace or hope for the future in the city, moreover, it seems to imprison him. Henryk Głuchowski walks around the city, sits in a cafe, looks at the city and people.

The Warsaw sequence, along with retrospective scenes from prison, is one of the best from Polish cinema in the early 1960s. Such images of Gomulka-era Warsaw cannot be found in the film archives of those times. [...] In long passages, we see an alien, unfriendly city. The street landscape plays the role of persona dramatis, it is saturated with the mental state in which the hero is.[30]

Sometimes in the films there are traces of the past, which had not been erased by the war, but carefully hidden after 1945. In Powrót [Return] (1960) by Jerzy Passendorfer, a film onsidered to be prejudiced against Polish Home Army (especially after the changes introduced), Siwy comes from abroad to the city which he has not been to since the war.[31] There is a new normal life going on here, in which Siwy does no find a place. Warsaw is flourishing: on the one hand, the Palace of Culture and Science, and on the other new housing estates. However, there is one scene in Powrót [Return] that can be interpreted in two ways. The hero is looking for Sliska Street, but in the place where it should be located, the Palace dominates. The building catches the attention of the newcomer, dominates Warsaw, but Powrót [Return] unambiguously indicates that Warsaw is a kind of a palimpsest. The hero's car drives over the sign "Here was Sliska Street" on the ground, but he will not pay attention to it. In Ktokolwiek wie... [Whoever may Know...] Maria's sister is sent to 56 Złota Street, but there is no such address. This place has been taken over by the Palace of Culture and Science, too.

Sometimes the image of Warsaw in the cinema of that time seems surprisingly subversive, although it may be a matter of contemporary interpretation. In Zagraniczny gość [The Foreign Guest], one of episodes of Jerzy Gruza's Wojna domowa (1965) [Civil War], we deal with a rather polite satire on the schematic perception of the city, but on the other hand, one can see in it a negation, though not very clearly articulated, of the message contained in most films about Warsaw. Paweł Jankowski takes his cousin from England on a trip. A snowstorm seriously hinders visiting the city, even the Palace of Culture and Science disappears in it. There is almost nothing to be seen through the frozen windows of the bus. When Rysio tries to figure out where they are, Paweł replies: "You better listen to the guide, you will find out where we are." Therefore, what is accessible is the official Warsaw, of which the guide, daringly played by Jacek Fedorowicz, talks (reminiscent of

[30] M. Hendrykowski, Stanisław Różewicz, Poznań 1999, pp. 55-56.
[31] T. Lubelski, Legenda Morza Sargassa, in: idem, Historia niebyła kina PRL, Kraków 2012, pp. 103-104. 
a fellow guide from the Przygoda na Mariensztacie [Adventure in Mariensztat]), with a bored voice giving "dates, facts, anecdotes." One can possibly see buildings, streets, monuments, but can one get to know the real Warsaw? Pawel, a Varsovian, who is not interested in this trip, is aware of it. His emotions will be aroused only by the possibility of looking at the entry phone. As suggested by the guide, who says that the trip will stop in front of "just the first newly built house on the way," there are a lot of these devices. There is no doubt, however, that this is where every trip comes (although there were several buildings with an entry phone). Warsaw's modernity had its limitations, which was shown with humour in Wojna domowa [Civil War].

Warsaw was supposed to be modern and remembering its past, joyful and serious, invariably beautiful. Henryk Kluba in Szkice warszawskie (1969) [Warsaw Sketches] [32] attempted to create such a synthetic image of the city. Three short features: a war film Allegro, a social drama Allegro Vivace and a comedy ... Ad Libitum, each kept in a different poetics, were to present Warsaw and its inhabitants in various situations and historical periods (in fact, the working title was Warszawiacy [Warsaw Residents]). The film was not well received. Doubts were already aroused by the starting point.

An ambitious intention - Aleksander Jackiewicz wrote - but not to be implemented. What does it mean: a comprehensive characterization of the city's residents? And how can this be done in one film, especially about Warsaw, a city with such a turbulent history and such a complex face?[33]

Yes, probably such a synthesis was not possible, for a variety of reasons connected with: film, culture, politics, etc. Anyway, just as Jackiewicz wrote, in a city like this it is impossible to be implemented. It must be admitted, however, that Kluba managed to include in $\mathrm{Sz}$ kice... [Sketches...] anthology, although of course incomplete, of the dominating representations of the capital presented in the cinema of the 1960 s, a combination of functions and features that constituted the film image of Warsaw in that decade. But not only the real, but also the film Warsaw was a bit more complicated by then.

Brzostek B., Za progiem. Codzienność w przestrzeni publicznej Warszawy lat 19551970, Warszawa 2007

Czubaj M., Etnolog w Mieście Grzechu. Powieść kryminalna jako świadectwo antropologiczne, Gdańsk 2010

Ćwikiel A., U nas na komendzie, in: Syndrom konformizmu? Kino polskie lat sześćdziesiatych, ed. T. Miczka, A. Madej, Katowice 1994

Dabert D., Jest dobrze. O ironiczności Wniebowziętych Andrzeja Kondratiuka, in: Poloniści o filmie, ed. M. Hendrykowski, Poznań 1997 
Dabert-Bakuła D., Prowizoryczny świat na stałe. O peerelowskich szarościach $w$ filmie lat 70. $i$ 80., "Images" 2004, no. 3-4

Eberhardt K., Świadectwo prawdy, świadectwo mitu, "Ekran” 1969, no. 35

Gomułka W., O aktualnych problemach ideologicznej pracy partii, wygłoszony 4 lipca 1963 r., in: idem, O naszej partii, Warszawa 1968

Helman A., Ballady warszawskie, "Kino" 1969, no. 12

Hendrykowski M., Stanisław Różewicz, Poznań 1999

Jackiewicz A., Antologia Kluby, in: idem, Moja filmoteka. Kino polskie, Warszawa 1983

Klejsa K., Stanisław Bareja - nadrealizm socjalistyczny, in: Mistrzowie kina polskiego, vol. 2, ed. G. Stachówna, B. Zmudziński, Kraków 2007

Lubelski T., Legenda Morza Sargassa, in: idem, Historia niebyła kina PRL, Kraków 2012

Majewski J., Ostatni klaps. Pamiętnik moich filmów, Warszawa 2006

Mazierska E., Janusowe oblicze filmowego miasta, "Kwartalnik Filmowy" 1999, no. 28

Nowakowski M., Pióro. Autobiografia literacka, Warszawa 2012

Ozimek S., Film dokumentalny, in: Historia filmu polskiego, vol. 6, 1968-1972, ed. R. Marszałek, Warszawa 1994

Ozimek S., Od wojny w dzień powszedni, in: Historia filmu polskiego, vol. 4, 19571961, ed. J. Toeplitz, Warszawa 1980

Smak impasu, interview by Bożena Janicka, "Kino" 1969, no. 12

Smoleń M., Pod warszawskim adresem: wyobrażenia i realia. Dokumentalne opowieści o stolicy, jej mieszkańcach i prowincjonalnych "słoikach", "Images" 2013, no. 21

Sołtysiak G., Filmowy przewodnik po Warszawie, Warszawa 2007

Talarczyk-Gubała M., PRL się śmieje! Polska komedia filmowa lat 1945-1989, Warszawa 2007

Uchwała Sekretariatu KC w sprawie kinematografii, in: Syndrom konformizmu? Kino polskie lat sześćdziesiątych, ed. T. Miczka, A. Madej, Katowice 1994

Zwierzchowski P., Kino nowej pamięci. Obraz II wojny światowej w kinie polskim lat 60., Bydgoszcz 2013 